\title{
Non-viraemic transmission of tick-borne viruses
}

\author{
S. HAVLÍKOVÁ ${ }^{1}$, M. LIČKOVÁ ${ }^{1}$, B. KLEMPA ${ }^{1,2}$ \\ ${ }^{1}$ Institute of Virology, Slovak Academy of Sciences, Dúbravská cesta 9, 84505 Bratislava, Slovak Republic; ${ }^{2}$ Institute of Virology, \\ Helmut-Ruska-Haus, Charité School of Medicine, Berlin, Germany
}

\begin{abstract}
Summary. - Tick-borne viruses are causative agents of several important human diseases. Tick-borne encephalitis virus (TBEV) is the most prominent representative considered medically to be the most important arbovirus (arthropod-borne virus) in Europe and northern Asia. Tick-borne virus transmission cycles are determined by the interactions between viruses, vectors, and their vertebrate hosts. Several mechanisms of tick-borne virus circulation in nature are currently considered to include transovarial transmission via the eggs from an infected female tick to its offspring, "viraemic" transmission between host and tick via feeding on a viraemic, infectious vertebrate hosts, and the virus transmission between co-feeding ticks, termed non-viraemic transmission (NVT). For NVT, the local skin site where ticks aggregately feed is an important focus of viral replication where migratory immune cells provide a vehicle for virus transmission from infected to uninfected co-feeding ticks. For TBEV at least, NVT is an important mechanism of virus maintenance in nature and offers explanations for some specific aspects of tick-borne virus ecology such as focal virus distribution and vector competency of particular tick species.
\end{abstract}

Keywords: routes of transmission; non-viraemic transmission; arbovirus; tick-borne viruses; co-feeding; tick-borne encephalitis virus

\section{Contents:}

1. Introduction

2. Tick-borne viruses

3. Routes of tick-borne virus transmission in nature

4. Non-viraemic transmission between co-feeding ticks

\section{Introduction}

Arboviruses (arthropod-borne viruses) are a unique biological group of viruses which contain several important human pathogens and have in recent years shown a great potential to emerge in new geographical regions and cause significant outbreaks. Tick-borne viruses represent an

E-mail: virusaha@savba.sk; phone: +421-2-59302428.

Abbreviations: ASFV = African swine fever virus; $\mathrm{CCH}$ $\mathrm{FV}=$ Crimean-Congo hemorrhagic fever virus; NVT = nonviraemic transmission; $\mathrm{SAT}=$ saliva-activated transmission; $\mathrm{SGE}=$ salivary gland extract $\mathrm{THOV}=$ Thogoto virus; $\mathrm{TBEV}=$ tick borne encephalitis virus important part of the group with tick-borne encephalitis virus (TBEV) and Crimean-Congo hemorrhagic fever virus (CCHFV) as two examples of viruses gaining recently growing public health interest due to their increasing incidence. Research on arboviruses and particularly TBEV ecology has a long-lasting tradition at the Institute of Virology of the Slovak Academy of Sciences in Bratislava. The scope of this minireview is to summarize current knowledge on tick-borne virus transmission with particular emphasis on TBEV and studies on non-viraemic transmission (NVT) performed in this laboratory.

\section{Tick-borne viruses}

Arboviruses belong to the largest biological group of vertebrate viruses characterized by their specific transmission via blood-feeding arthropods. Arboviruses are different from other viruses in their ability to replicate in both vertebrate and invertebrate cells. With a single exception, all arboviruses are RNA viruses. So far the only DNA arbovirus is African swine fever virus (ASFV). More than 500 
Table 1. Reports on non-viraemic transmission and basic characteristics of the most prominent representatives of tick-borne viruses

\begin{tabular}{|c|c|c|c|c|}
\hline Family/virus & Vector & Non-viraemic transmission & Disease & Reported occurrence \\
\hline \multicolumn{5}{|l|}{ Flaviviridae } \\
\hline Tick-borne encephalitis virus & $\begin{array}{l}\text { Ixodes ricinus } \\
\text { I. persulcatus }\end{array}$ & $\begin{array}{l}\text { Labuda et al. (1993a,c) } \\
\text { Labuda (1996) }\end{array}$ & human encephalitis & Europe, Asia, Siberia \\
\hline Powassan virus & I. cookei & - & human encephalitis & Canada \\
\hline Louping ill virus & I. ricinus & Jones et al. (1997) & Louping ill of sheep & UK \\
\hline $\begin{array}{l}\text { Omsk hemorrhagic fever } \\
\text { virus }\end{array}$ & Dermacentor reticulatus & - & human hemorrhagic fever & Siberia \\
\hline Kyasanur Forest disease virus & Argas persicus & Singh et al. (1971) & human hemorrhagic disease & India \\
\hline Langat virus & I. granulatus & - & - & Malaysia \\
\hline Royal Farm virus & A. hermanni & - & - & Afghanistan \\
\hline Karshi virus & Ornithodoros papillipes & - & - & Kazakhstan, Uzbekistan \\
\hline \multicolumn{5}{|l|}{ Bunyaviridae } \\
\hline $\begin{array}{l}\text { Crimean-Congo hemor- } \\
\text { rhagic fever virus }\end{array}$ & Hyalomma marginatum & $\begin{array}{l}\text { Gonzalez et al. (1992) } \\
\text { Gordon et al. (1993) }\end{array}$ & human hemorrhagic disease & $\begin{array}{l}\text { Asia, Africa, partly Europe } \\
\text { (Albania, Bulgaria) }\end{array}$ \\
\hline Uukuniemi virus & I. ricinus & - & - & Europe, Lithuania \\
\hline Nairobi sheep disease virus & $\begin{array}{l}\text { Rhipicephalus appendicu- } \\
\text { latus }\end{array}$ & - & fever, arthralgia in sheep & Africa \\
\hline Bhanja virus & Haemaphysalis intermedia & Labuda et al. (1997a) & - & Africa, Asia, Europe \\
\hline Palma virus & H. punctata & Labuda et al. (1997a) & - & Portugal \\
\hline \multicolumn{5}{|l|}{ Reoviridae } \\
\hline Tribeč & I. ricinus & - & fever or encephalitis in human & Slovakia, Italy, Belorussia \\
\hline Kemerovo & I. persulcatus & - & - & Russia, Slovakia \\
\hline Lipovnik & I. ricinus & - & - & Slovakia, Czech Republic \\
\hline Coltivirus Eyach & I. ricinus & - & - & Germany, France \\
\hline Colorado tick fever virus & D. andersoni & - & human encephalitis & USA \\
\hline \multicolumn{5}{|l|}{ Orthomyxoviridae } \\
\hline Thogoto & $\begin{array}{l}\text { Rhipicephalus, Boophilus, } \\
\text { Hyalomma }\end{array}$ & Jones et al. (1987) & $\begin{array}{l}\text { human encephalitis and } \\
\text { hepatitis }\end{array}$ & Africa, Europe \\
\hline Dhori & $\begin{array}{l}\text { H. dromedarii, H. mar- } \\
\text { ginatum }\end{array}$ & - & $\begin{array}{l}\text { fever and encephalitis in } \\
\text { human }\end{array}$ & India, Russia, Egypt, Portugal \\
\hline \multicolumn{5}{|l|}{ Asfaviridae } \\
\hline African swine fever virus & O. moubata, O. erraticus & - & hemorrhagic fever in swine & Africa, Europe, S. America \\
\hline
\end{tabular}

arboviruses are registered in the International Catalogue of Arboviruses (Karabatsos, 1985). Approximately 50\% of them are mosquito-borne while $25 \%$ are transmitted by ticks. The rest are transmitted by sand flies and biting midges. Tickborne viruses belong to five families. Most of them belong to the families Bunyaviridae, Flaviviridae, and Togaviridae while only a small proportion of arboviruses belong to the Reoviridae and Orthomyxoviridae families (Table 1).

Most of the studies on interactions of arboviruses and their vectors are focused on those which are transmitted via mosquitoes as vectors. However, ticks substantially differ from mosquitoes and have some specific biological features such as blood feeding, bloodmeal digestion, molting and longevity which undoubtedly influence arbovirus infection, replication, persistence and transmission (Sonenshine, 1991). In general, the association between tick and transmitted virus is very intimate and highly specific. Comparatively few arthropods act as vectors of viruses. In fact, less than
$10 \%$ of known tick species are incriminated as virus vectors and they are mostly found in large tick genera. Virus vectors are found mainly in the genera Ixodes, Haemaphysalis, Hyalomma, Amblyomma, Dermacentor, Rhipicephalus, and Boophilus (Labuda and Nuttall, 2004).

Most tick vector species transmit one or two virus species. Only a few species transmit several viruses such as Ixodes ricinus. This tick is the main vector of viruses from three virus families, TBEV and Louping ill virus of the family Flaviviridae, Tribeč virus, and Eyach virus of the Reoviridae and Uukuniemi of the Bunyaviridae family (Labuda and Nuttall, 2004).

Tick-borne viruses occur also in a virus family not typically considered as an arbovirus family. The Orthomyxoviridae family is well-known through three genera of influenza viruses. In addition to these respiratory viruses, the fourth genus in the family (Thogotovirus) also comprises tick-borne viruses Thogoto virus (THOV) and Dhori virus. These vi- 
ruses contain surface glycoprotein that is unrelated to any influenza viral protein but instead shows sequence homology to a baculovirus surface glycoprotein (Morse et al., 1992). This unique glycoprotein is probably the key to the ability of both viruses to infect ticks (Nuttall et al., 1995).

ASFV is the only recognized DNA virus within arboviruses. ASFV is maintained through ticks Ornithodoros moubata and warthogs (Phacochoerus spp.) in sylvatic transmission cycle in Africa (Jori et al., 2012). In addition, some recent studies suggest that ticks may also play a role in the circulation of another DNA virus, Murid herpes virus 4, strain MHV-68 (Ficová et al., 2011; Hajnická et al., submitted).

More than 150 arboviruses have been documented to cause human disease including several important human pathogens such as Dengue virus, Yellow fever virus, West Nile virus, or Japanese encephalitis virus, which are transmitted by mosquitoes. Several medically important diseases are also caused by tick-borne viruses. TBEV is considered to be the most important arboviral pathogen in Europe causing more than 10,000 clinical cases of tickborne encephalitis annually. Other relevant tick-borne viruses causing encephalitis in humans are Powassan virus, Tribeč virus, Kemerovo virus, and Colorado tick fever virus. CCHFV causes hemorrhagic fever with severe typhoid-like symptoms and mortality rates of up to $50 \%$. Hemorrhagic diseases are also caused by Omsk hemorrhagic fever virus and Kyasanur Forest disease virus (Table 1) (Labuda and Nutall, 2004; Cleton et al., 2012).

The routes of human infection by tick-borne viruses have been described in the most detail for TBEV. The most common way for humans to become infected with tick-borne viruses is to be bitten by an infected tick in forest areas where dense vegetation provides good conditions for ticks (Gritsun et al., 2003). The major factor contributing to the incidence of the disease in humans is an abundance of ticks containing a sufficient dose of infectious virus (Korenberg and Kovalevskii, 1999). A second natural route for the acquisition of tick-borne viruses is alimentary infection. Alimentary route involves dairy products from livestock. Large domestic animals (goats, sheep and cattle) are potential hosts for ticks and may become infected by TBEV in endemic foci. During the viraemic stage, the virus is excreted in milk and can be ingested orally by consumption of products from raw milk (Grešíková, 1958a,b). Typically, small family epidemics may occur. In addition to tick bites and alimentary transmission, other routes of transmission have been described, e.g. laboratory infections (Avšič-Županc et al., 1995), blood transfusions (Wahlberg et al., 1989), viraemic goat slaughter (Kräusler, 1981) and transmission from a viraemic mother to a child per breast milk (Vaisviliene, 1997). For CCHFV, contact with blood or tissue from viraemic livestock is a significant means of infection. Moreover, nosocomial outbreaks of CCHFV can also occur (Aradaib et al., 2010).

\section{Routes of tick-borne virus transmission in nature}

Tick-borne virus transmission cycles are determined by the interactions between viruses, vectors, and their vertebrate hosts and have been mainly elucidated by studies on TBEV (Nuttall, 1999). Several mechanisms of virus circulation in nature are currently known. Vertical transmission of the virus in the form of transovarial transmission of the virions via the eggs from an infected adult female tick to its offspring has been documented but seems to be ineffective and its importance to the maintenance of the virus in nature is considered to be rather low (Benda, 1958; Danielová et al., 2002; Nutall and Labuda, 2003; Randolph, 2004). The decisive role in the maintenance of tick-borne viruses in nature can be therefore attributed to the horizontal means of virus transmission described below.

For decades, it was thought that the main route of TBEV and other tick-borne viruses transmission to ticks was by systemic infection-transmission between host and tick via feeding on viraemic, infectious vertebrate hosts, mainly rodents (Blaškovič, 1967). In this concept, the viruses are imbibed by ticks from an infected donor vertebrate, multiplied in tick organism and delivered to uninfected vertebrate host. However, the virus is present only for a few days at the sufficient high concentration in the blood of infected rodents. It is considered to be insufficient time or dose to infect a sufficient number of ticks to maintain the transmission cycle of TBEV (Nuttall and Labuda, 2003; Randolph et al., 1996). Although recent fields and laboratory studies have shown that TBEV-RNA is detectable in the organs of rodents for longer periods (Achazi et al., 2011; Knap et al., 2012), it is questionable whether the detection of virus RNA resembles transmissibility of the virus to ticks.

Nevertheless, this so called "viraemic" or "systemic" way of transmission from persistently infected rodents has recently been proposed to play a role in virus overwintering (Bakhvalova et al., 2006, 2009; Tonteri et al., 2011). On the other hand, virus overwintering in ticks has also been clearly documented. TBEV has been detected in nymphs and adult ticks questing during the spring and early summer (Carpi et al., 2009; Durmisi et al., 2011) indicating that the virus has survived over winter in these ticks because they would have moulted from engorged larvae the previous autumn (Randolph et al., 2002; Randolph, 2011).

In addition to rodents, large mammals such as deer, goats, sheep and cattle can be infected and become viraemic too. Their direct contribution to virus maintenance is probably of little importance. However, they influence the transmission cycle through the fact that they are the main hosts for the reproducing adult $I$. ricinus ticks (Jaenson et al., 2012).

Within the last 20 years, it has become obvious that viraemia of the vertebrate host is not necessary for successful TBEV transmission and that the virus can be transmitted 
from infected to non-infected ticks when they co-feed in close proximity on the same host. This virus transmission between co-feeding ticks, termed non-viraemic transmission (NVT) is the main topic of the following chapter.

\section{Non-viraemic transmission}

The phenomenon of viraemia in arbovirus transmission was first contradicted by Jones et al. (1987) when they showed that THOV could be efficiently transmitted between Rhipicephalus appendiculatus nymph ticks co-feeding with infected adult ticks on non-viraemic guinea pigs even though they were physically separated (Table 1).

Similar results were soon obtained with more typical arbovirus, Western subtype of TBEV, medically the most important arbovirus in Europe and northern Asia. Initial studies reported NVT between TBEV infected and noninfected ticks I. ricinus, Ixodes persulcatus, Dermacentor marginatus, Dermacentor reticulatus, and $R$. appendiculatus feeding together on non-viraemic guinea pigs (Alekseev and Chunikhin, 1990; Labuda et al., 1993a) (Table 1).

Labuda et al. (1993c) then focused further on elucidation and whether NVT plays a role in the circulation of TBEV in nature. The aims of the study were to determine the efficiency of tick to tick TBEV transmission involving different natural host species of $I$. ricinus and the contribution of viraemia developed by the hosts to TBEV transmission between cofeeding ticks. In their co-feeding experiments, they showed that some free-living animals such as hedgehogs (Erinaceus europaeus) and pheasants (Phasianus colchicus) neither developed systemic infection nor supported transmission of TBEV between co-feeding ticks. In contrast, pine voles (Pitymys subterraneus) were highly susceptible to the virus and supported transmission, but few nymphs completed engorgement. The most important results were obtained with field mice (Apodemus flavicollis and Apodemus agrarius) and bank voles (Myodes glareolus). A significantly higher proportion of ticks became infected when co-feeding on Apodemus species compared with bank voles (67.7\% vs. $27.7 \%)$. Most interestingly, Apodemus mice had very low or undetectable levels of viraemia. In the follow-up study, A. flavicollis and M. glareoulus were first immunized against TBEV and then challenged by infected and uninfected ticks. Despite the presence of neutralizing antibodies, $89 \%$ of the immune animals supported virus transmission between co-feeding ticks. The ability of TBEV-immune natural hosts with no detectable viraemia still to support virus transmission has important epidemiological implications relating to the survival of TBEV in nature (Labuda et al., 1997b).

NVT has meanwhile been documented for several other tick-borne viruses (Table 1) clearly showing that it is no exceptional or optional route of transmission but rather a general mechanism of circulation of tick-borne viruses in nature. Jones et al. (1997) showed that uninfected ticks became infected when they co-fed with Louping ill infected ticks on apparently non-viraemic wild-caught hares. NVT was reported also for Kyasanur Forest disease virus by soft tick Argas persicus on domestic chick (Singh et al., 1971). CCHFV was transmitted from infected adult to uninfected larval and nymphal Hyalomma ticks while co-feeding on a guinea pig host that did not have detectable viraemia (Gordon et al., 1993). Moreover, Gonzalez et al. (1992) found, in addition to sexual and transovarial transmission of CCHFV, NVT between co-feeding adults Hyalomma truncatum ticks. Palma and Bhanja bunyaviruses were transmitted to various tick species (D. marginatus, D. reticulatus, Rhipicephalus sanguineus, R. appendiculatus) while co-feeding with infected ticks on laboratory mice which developed very low viraemia (Labuda et al., 1997a).

An obvious prerequisite for NVT is the simultaneous feeding of infected and uninfected ticks (co-feeding) on the competent host. Ticks feed in clumps on hosts, most hosts carry few ticks, but a small portion (20\%) carries the majority of ticks (80\%) (Randolph et al., 1999). Tick feeding aggregation reduces the distance between co-feeding infected and uninfected ticks, thereby facilitating NVT (Labuda et al., 1996, 1997b). Skin explants of tick feeding sites were shown to contain numerous migratory Langerhans cells and neutrophils containing viral antigen. Moreover, migratory monocyte/macrophages were shown to produce infectious virus. Furthermore, virus was recruited preferentially to the site in which ticks were feeding compared with uninfested skin sites. Based on these observations, one can conclude that the local skin site of feeding ticks is thus an important focus of viral replication early after TBEV transmission by ticks. Cellular infiltration of tick feeding sites, and the migration of cells between such sites provides a vehicle for transmission between co-feeding ticks that is independent of a patent viraemia (Labuda et al., 1996).

It was then shown that exploitation of the local skin site leading to NVT is promoted by molecule(s) synthesized in the salivary glands during tick feeding and secreted via saliva into the skin feeding lesion. The phenomenon was named saliva-activated transmission (SAT) (Nuttall and Jones, 1991) and was demonstrated previously for other tick-borne pathogens. Titus and Ribeiro (1988) revealed that Leishmania infectivity was enhanced by salivary gland extract (SGE) from sandflies.

The first evidence that virus transmission may be enhanced due to tick SGE was revealed by Jones et al. (1989), when they showed that 10 times more nymphs became infected with THOV by feeding on guinea pigs inoculated with a mixture of THOV and SGE than by feeding on guinea pigs inoculated with virus alone. The number of infected ticks was greatest when the SGE were derived from unin- 
fected partially fed ticks and when the virus with SGE was inoculated at the same skin site.

To investigate the involvement of salivary gland products in TBEV transmission, SGE were prepared from partially fed uninfected female $I$. ricinus, D. reticulates, and $R$. appendiculatus ticks. Guinea pigs were infested with uninfected $R$. appendiculatus nymphs and inoculated with a mixture of TBEV plus SGE or TBEV alone. The number of infected ticks that acquired TBEV by feeding on animals inoculated with the mixture of TBEV with SGE from partially fed ticks was 4-fold greater than the number of infected ticks by feeding on animals inoculated with TBEV alone or TBEV plus SGE from unfed $I$. ricinus ticks. This was the first evidence that TBEV transmission is enhanced by factors associated with the salivary glands of feeding ticks and that these factors may facilitate efficient transmission of TBEV between ticks even when they feed on non-viraemic host (Labuda et al., 1993b).

The primary function of the SAT factors, which are anti-hemostatic, anti-inflammatory molecules or immunomodulators, is to modulate the skin site of attachment thereby facilitating feeding and virus transmission. Tickborne viruses in which was demonstrated SAT appear to have co-evolved with their vectors and hosts to employ the unique environment of the vector-host interface (Nuttall, 1998; Nuttall and Labuda, 2003).

Knowledge accumulated indicates that NVT plays not only an important role but a crucial one in the maintenance of the virus in the natural endemic cycle. Randolph et al. (1996) compared the relative contribution of non-viraemic with viraemic transmission to the maintenance of TBEV in rodent population by employing mathematical modelling. The number of infective ticks yielded from one infected tick bite on susceptible host (reproductive number, $\mathrm{R}_{0}$ ) was studied as a result of comparison of several parameters (host survival and transmission coefficient from tick to vertebrate; duration of infectivity of host, tick infestation levels and transmission coefficient from vertebrate to tick; transmission coefficient from tick to tick and tick survival). This quantitative comparison of $\mathrm{R}_{0}$ values for viraemic and non-viraemic transmission indicated that the non-viraemic pathway yields a $>50 \%$ increase in the amplification of TBEV than the classically supposed systematic pathway.

Following this concept, one can see the tick-borne pathogens as being transmitted from tick to tick via vertebrates with the ticks as the reservoirs as well as the vectors, while the vertebrate is the transient bridge (Randolph, 2011). An important aspect of the NVT of TBEV during co-feeding is that it occurs typically between tick nymphs and larvae. The distributions of larvae and nymphs on their principal rodent hosts are highly aggregated. Essential for coincident aggregated distributions of larvae and nymphs is their synchronous seasonal activity which occurs only in certain places but not throughout the entire I. ricinus geographical range. This therefore seems to be the critical factor for the maintenance of TBEV which explains the focal distribution of TBEV and which is mostly likely influenced by microclimate conditions. The synchronous seasonal activity distributions of larvae and nymphs as a key factor and also provide an explanation as to why $I$. ricinus and $I$. persulcatus appear to be the only vectors and reservoirs of TBEV in nature although at least 18 tick species were shown to be able to transmit the virus in the laboratory. Hence, it is not the specific virus susceptibility of certain tick species but their intimate ecological association with transmission competent vertebrate hosts that are critical for their role as virus vectors (Labuda and Randolph, 1999; Randolph et al., 1999; Randolph, 2011).

In recent years, the efficiency of NVT between co-feeding ticks has been studied as a crucial part of the evaluation of anti-tick vaccine candidates using the TBEV-tick-mouse model established in studies described above. The protective effect of immunization with tick cement protein 64TRP (Trimnell et al., 2002, 2003, 2005; Havlíková et al., 2009) in comparison with the commercial TBEV vaccine and antitick vaccine TickGard was based on the mouse laboratory model in which mice were infested with TBEV infected ticks (Labuda et al., 2006). Neither commercial vaccine was as effective as 64TRP in controlling TBEV transmission from the infected tick to uninfected co-feeding ticks. Those results confirmed the previous study where natural rodent hosts immune to TBEV supported co-feeding virus transmission (Labuda et al., 1997b) and indicated a higher level of virus infection in virus-immune mice in comparison with tick-immune mice. 64TRP also affected transmission of TBEV from infected mouse to non-infected co-feeding nymphs (Labuda et al., 2006). This study indicated that immunization against proteins involved in SAT might prevent NVT of TBEV and might be a promising strategy to prevent tick-borne diseases.

Quite surprising data was obtained with another tick protective antigen, subolesin (SUB) involved in tick innate immunity (Almazán et al., 2003, 2005; de la Fuente et al., 2006). The vaccination with recombinant SUB neither prevented NVT of TBEV nor protected mice from fatal TBEV infection. Levels of TBEV infection were 10-fold higher in nymphs (similar to adults) fed on vaccinated than on control mice (Havlíková et al., 2013). This data suggests that efficiency of NVT during co-feeding is influenced by tick innate immunity, probably through controlling the virus replication in ticks during their feeding.

Khasnatinov et al. (2009) studied the molecular mechanism of adaptation of TBEV strains to different tick species. Analyses of atypical, hemagglutinating-deficient Siberian strains revealed 3 unique amino acid substitutions in the envelope protein. Unexpectedly, these mutations when introduced to genetically modified viruses caused increased TBEV 
reproduction in feeding $I$. ricinus ticks, not the recognized tick host for these strains, and increased efficiency of NVT between ticks co-feeding on mice. This study suggests that NVT efficiency might be a driving force in evolution and adaption of viruses to novel ticks and might be mediated through changes in the envelope protein.

In summary, the discovery of NVT between co-feeding ticks as a novel route of tick-borne virus transmission about 20 years ago dramatically influenced arbovirus research and changed our understanding of tick-borne virus ecology. Although the relative contribution of non-viraemic vs. viraemic transmission to the maintenance of TBEV in rodent population might still be a matter of scientific discussion, the accumulated knowledge described above clearly demonstrates that it is an important mechanism of virus maintenance in nature and offers explanations for some specific aspects of tick-borne virus ecology such as focal distribution and vector competency of particular tick species at least for TBEV.

Acknowledgement. This work was supported by the Research \& Development Operational Programme funded by the ERDF (project no. ITMS 26240220044) and Slovak Scientific Grant Agency VEGA (grant no. 2/0191/12).

Conflict of interest. The authors declare that there is no conflict of interest with the ideas put forward in the final version of manuscript.

\section{References}

Achazi K, Růžek D, Donoso-Mantke O, Schlegel M, Ali HS, Wenk M, Schmidt-Chanasit J, Ohlmeyer L, Ruhe F, Vor T, Kiffner C, Kallies R, Ulrich RG, Niedrig M, Vector Borne Zoon. Dis. 11, 641-647, 2011. http://dx.doi.org/10.1089/ vbz.2010.0236

Alekseev AN, Chunikhin SP, Med. Parazitol. 2, 48-50, 1990.

Almazán C, Kocan KM, Bergman DK, Garcia-Garcia JC, Blouin EF, de la Fuente J, Vaccine 21, 1492-1501, 2003. http:// dx.doi.org/10.1016/S0264-410X(02)00683-7

Almazán C, Blas-Machado U, Kocan KM, Yoshioka JH, Blouin EF, Mangold AJ, de la Fuente J, Vaccine 23, 4403-4416, 2005. http://dx.doi.org/10.1016/j.vaccine.2005.04.012

Aradaib IE, Erickson BR, Mustafa ME, Khristova ML, Saeed NS, Elageb RM, Nichol ST, Emerg. Infect. Dis. 16, 837-839, 2010. http://dx.doi.org/10.3201/eid1605.091815

Avšič-Županc T, Poljak M, Maticic M, Clin. Diagn. Virol. 4, 51-59, 1995. http://dx.doi.org/10.1016/0928-0197(94)00062-Y

Bakhvalova VN, Dobrotvorsky AK, Panov VV, Matveeva VA, Tkachev SE, Morozova OV, Vector-Borne Zoonotic. Dis. 6, 32-41, 2006. http://dx.doi.org/10.1089/vbz.2006.6.32

Bakhvalova VN, Potapova OF, Panov VV, Morozova OV, Virus Res., 140, 172-178, 2009. http://dx.doi.org/10.1016/j. virusres.2008.12.001

Benda R, J. Hyg. Epidemiol. Microbiol. Immunol. 2, 314-330, 1958.
Blaškovič D, Bull. WHO. 36 (S1), 5-13, 1967.

Carpi G, Bertolotti L, Rosati S, Rizzoli A, J. Gen. Virol. 90, 28772883, 2009. http://dx.doi.org/10.1099/vir.0.013367-0

Cleton N, Koopmans M, Reimerink J, Godeke GJ, Reusken C, J. Clin. Virol. 55, 191-203, 2012. http://dx.doi.org/10.1016/j. jcv.2012.07.004

Danielová V, Holubová H, Pejčoch M, Daniel M, Folia Parasitol. 49, 323-325, 2002.

de la Fuente J, Almazán C, Blas-Machado U, Naranjo V, Mangold AJ, Blouin EF, Gortazar C, Kocan KM, Vaccine 24, 4082-4095, 2006. http://dx.doi.org/10.1016/j.vaccine.2006.02.046

Durmisi E, Knap N, Saksida A, Trilar T, Duh D, Avšič-Županc T, Vector-Borne Zoonotic. Dis. 11, 659-664, 2011. http:// dx.doi.org/10.1089/vbz.2010.0054

Ficová M, Betáková T, Pančík P, Václav R, Prokop P, Halásová Z, Kúdelová M, Microb. Ecol. 62, 862-867, 2011. http:// dx.doi.org/10.1007/s00248-011-9907-7

Gonzalez JP, Camicas JL, Cornet JP, Faye O, Wilson ML, Res. Virol. 143, 23-28, 1992. http://dx.doi.org/10.1016/S09232516(06)80073-7

Gordon SW, Linthicum KJ, Moulton JR, Am. J. Trop. Med. Hyg. 48, 576-580, 1993.

Grešíková M, Acta Virol. 2, 113-119, 1958a.

Grešíková M, Acta Virol. 2, 188-192, 1958b.

Gritsun TS, Lashkevich VA, Gould EA, Antiviral Res. 57, 129-46, 2003. http://dx.doi.org/10.1016/S0166-3542(02)00206-1

Havlíková S, Roller L, Koči J, Trimnell AR, Kazimírová M, Klempa B, Nuttall PA, Int. J. Parasitol. 39, 1485-1494, 2009. http:// dx.doi.org/10.1016/j.ijpara.2009.05.005

Havlíková S, Ličková M, Ayllón N, Roller L, Kazimírová M, Slovák M, Moreno-Cid JA, Pérez de la Lastra JM, Klempa B, de la Fuente J, Vaccine 31, 1582-1589, 2013. http://dx.doi. org/10.1016/j.vaccine.2013.01.017

Jaenson TG, Hjertqvist M, Bergström T, Lundkvist A, Parasit Vectors 5, 1-13, 2012. http://dx.doi.org/10.1186/17563305-5-1

Jones LD, Davies CR, Steele GM, Nuttall PA, Science 237, 775-777, 1987. http://dx.doi.org/10.1126/science. 3616608

Jones LD, Hodgson E, Nuttall PA, J. Gen. Virol. 70, 1895-1898, 1989. http://dx.doi.org/10.1099/0022-1317-70-7-1895

Jones LD, Gaunt M, Hails RS, Laurenson K, Hudson PJ, Reid H, Henbest P, Gould EA, Med. Vet. Entomol. 11, 172176, 1997. http://dx.doi.org/10.1111/j.1365-2915.1997. tb00309.x

Jori F, Vial L, Penrith ML, Pérez-Sánchez R, Etter E, Albina E, Michaud V, Roger F, Virus Res. http://dx.doi. org/10.1016/j.virusres.2012.10.005, 2012. http://dx.doi. org/10.1016/j.virusres.2012.10.005

Karabatsos N, International Catalogue of Arboviruses Including Certain Other Viruses of Vertebrates, Third edn. San Antonio, Texas, American Society of Tropical Medicine and Hygiene, 1985.

Khasnatinov MA, Ustanikova K, Frolova TV, Pogodina VV, Bochkova NG, Levina LS, Slovak M, Kazimirova M, Labuda M, Klempa B, Eleckova E, Gould EA, Gritsun TS, Plos One 4, e7295, 2009. http://dx.doi.org/10.1371/journal. pone.0007295 
Knap N, Korva M, Dolinšek V, Sekirnik M, Trilar T, Avšič-Županc T, Vector Borne Zoonotic Dis. 12, 236-242, 2012. http:// dx.doi.org/10.1089/vbz.2011.0728

Korenberg EI, Kovalevskii YV, Zentralbl. Bakteriol. 289, 525-539, 1999. http://dx.doi.org/10.1016/S0934-8840(99)80006-1

Kräusler J, In: Kunz C (Ed.): Tick-borne Encephalitis. Facultas, Vienna, Austria, pp. 6-12, 1981.

Labuda M, Jones LD, Williams T, Danielová V, Nuttall PA, J. Med. Entomol., 30, 295-299, 1993a.

Labuda M, Jones LD, Williams T, Nuttall PA, Med. Vet. Entomol. 7, 193196, 1993b. http://dx.doi.org/10.1111/j.1365-2915.1993. tb00674.x

Labuda M, Nuttall PA, Kožuch O, Elečková E, Williams T, Žuffová E, Sabó A, Experientia 49, 802-805, 1993c. http://dx.doi. org/10.1007/BF01923553

Labuda M, Austyn J, Žuffová E, Kožuch O, Fuchsberger N, Lysý J, Nuttall PA, Virology 219, 357-366, 1996. http://dx.doi. org/10.1006/viro.1996.0261

Labuda M, Alves MJ, Elečková E, Kožuch O, Filipe AR, Acta Virol. 41, 325-328, 1997a.

Labuda M, Kožuch O, Žuffová E, Elečková E, Hails RS, Nuttall PA, Virology 235, 138-143, 1997b. http://dx.doi.org/10.1006/ viro.1997.8622

Labuda M, Randolph SE, Zentbl. Bakteriol. 289, 513-524, 1999. http://dx.doi.org/10.1016/S0934-8840(99)80005-X

Labuda M, Nuttall PA, Parasitol. 129, S221-S245, 2004. http:// dx.doi.org/10.1017/S0031182004005220

Labuda M, Trimnell AR, Ličková M, Kazimírová M, Davies GM, Lissina O, Hails RS, Nuttall PA, PLoS Pathog. 2, 02510259, 2006.

Morse MA, Marriott AC, Nuttall PA, Virology 186, 640-646, 1992. http://dx.doi.org/10.1016/0042-6822(92)90030-S

Nuttall PA, Jones LD, In Dusbabek F, Bukva V (Ed.): Modern Acarology, Prague and The Hague, Academia and SPB Academic Publishing bv, pp. 3-6, 1991.

Nuttall PA, Morse MA, Jones LD, Portela A, In ed. Gibbs AJ, Calisher CH, Garcia-Arenal F, Molecular Basis of Virus evolution, Cambridge, Cambridge University Press, 416-425, 1995.
Nuttall PA, Parasitol. 116, S65-S72, 1998. http://dx.doi.org/10.1017/ $\underline{\text { S003118200008495X }}$

Nuttall PA, Zentralbl. Bakteriol. 289, 492-505, 1999. http://dx.doi. org/10.1016/S0934-8840(99)80002-4

Nuttall PA, Labuda M, Adv. Virus Res. 60, 233-272, 2003. http:// dx.doi.org/10.1016/S0065-3527(03)60007-2

Randolph SE, Gern L, Nuttall PA, Parasitol. Today 12, 472-479, 1996. http://dx.doi.org/10.1016/S0169-4758(96)10072-7

Randolph SE, Miklisová D, Lysý J, Rogers DJ, Labuda M, Parasitology 118, 177-186, 1999. http://dx.doi.org/10.1017/ $\underline{\text { S0031182098003643 }}$

Randolph SE, Chemini C, Furlanello C, Genchi C, Hails RS, In: Hudson PJ, Rizzoli A, Grenfell BT, The ecology of wildlife diseases. Oxford University Press, pp. 119-138, 2002.

Randolph SE, Parasitol. 129, S37-S65, 2004. http://dx.doi. org/10.1017/S0031182004004925

Randolph SE, Ticks Tick Borne Dis. 2, 179-182, 2011. http://dx.doi. org/10.1016/j.ttbdis.2011.07.004

Singh KR, Goverdhan MK, Bhat UK, Indian J. Med. Res. 59, 213 218, 1971.

Sonenshine DE, Biology of ticks. Vol. 1., Oxford University Press, New York, 447, 1991.

Titus RG, Ribeiro JMC, Science 239, 1306-1308, 1988. http://dx.doi. org/10.1126/science. 3344436

Tonteri E, Jääskeläinen AE, Tikkakoski T, Voutilainen L, Niemimaa J, Henttonen H, Vaheri A, Vapalahti O, Emerg. Infect. Dis. 17, 72-75, 2011. http://dx.doi.org/10.3201/eid1701.100051

Trimnell AR, Hails RS, Nuttall PA, Vaccine 20, 3560-3568, 2002. http://dx.doi.org/10.1016/S0264-410X(02)00334-1

Trimnell AR, Paesen GC, Nuttall PA, Vaccine comprising a tick cement protein. US Patent App. No. 10/280, 114, 2003.

Trimnell AR, Davies GM, Lissina O, Hails RS, Nuttall PA, Vaccine 23, 4329-4341, 2005. http://dx.doi.org/10.1016/j. vaccine.2005.03.041

Vaisviliene D, In Süss J, Kahl O (Eds.): Proc. 4th Int. Potsdam Symp. Lengerich, Pabst. Science Publishers, pp. 100-113, 1997.

Wahlberg P, Saikku P, Brummer-Korvenkontio M, J. Intern. Med. 225, 173-177, 1989. http://dx.doi.org/10.1111/j.1365-2796.1989. tb00059.x 